\title{
Wilhem Wied and the Movement of Northern Epirus: The Protocol of Corfu
}

\author{
$\mathrm{PhD}$ candidate Xhoana Faja
}

\author{
"Aleksandër Moisiu" University of Durrës \\ Faculty of Bisness, Departament of Tourism \\ xhoanafaja@live.com
}

\section{Doi:10.5901/mjss.2013.v4n10p715}

\begin{abstract}
After the independence of Albania, the six Great Powers decided that the throne of Albania would be given to a Western Prince, Wilhem von Wied, who would lead the country in a difficult moment and politically destabilized, and considering the territorial claims of the neighbor countries such as Serbia, Montenegro and Greece. Prince accepted the throne, and of course with the promise of help from the Great Powers. Obviously running a country, which besides, was unknown to the Prince, would present difficulties. A fundamental problem was the one that relates to a movement created by Athens, called "the movement for autonomy of Northern Epirus". A movement which was contrary to the decisions of the Great Powers, and of course was very problematic for the new Monarch. However, this event became even more complicated after the suggestion of The International Commission of Control, on some concessions to the "Vorio Epirotans". This led to the signing of an agreement with "Vorio-Epirus", in Corfu which is known as the" Protocol of Corfu ". Issues about "The Movement of Northern Epirus", the relations of Wied and his government with it will be considered more extensively in this study. The "Protocol of Corfu" issues. Why The Protocol of Corfu agreement was rejected by the government of Turhan Pasha and the reasons for its ratification by the same government will be considered as well.
\end{abstract}

Keywords: movement, autonomy, agreement, fighting, controversy, violation

\section{Introduction}

The decisions of the Conference of Ambassadors in London 1913, would lead to major changes in the Albanian cause. The main decisions were related to the definition of the borders and delimitation of the status of Albania. In the definition of the borders, decisions were taken considering the demands of neighboring countries, where the Albanian lands became a prey available to their territorial ambitions. From these decisions to Albania were aparted about three quarters of the land area and divided between Montenegro, Serbia, Macedonia and Greece. To determine these borders was decided to establish a committee to work at the place, called the International Commission of Control (Akademia e shkencave, 2007).

For determining the status of Albania they decided to turn it into an autonomous Principality, on top of which would set up a Prince, which will be determined by the Great Powers. For selecting the prince different figures were reviewed and among them were Western figures, some of which with royal descent. There were proposals for Mohammedan figures, but these figures were not suitable, especially for the situation in which Albania was after the declaration of Independence by the Turkish Empire. Even Albanian patriotic figures strongly opposed the election of a Mohammedan prince. Faik Konica, who was the representative of Vatra Federation, published an article at the press of the time, in which it argued that such a choice would be a setback for Albania, especially now that she wanted to turn the eyes to the West, by become part of European progress. (Faik Konica, 1913) After taking into account these candidates with the proposal of Austria-Hungary and Italy, it was decided that the King of Albania would be Prince Wilhem von Wied. This decision was well received by Albanian circles, hoping to create a united Albanian principality. There were circles who opposed this choice considering Wied as a man without political achievement and without prosperity, prosperity that is aiming to win in Albania (Tarabosh, 1913).

\section{The Movement of Northern Epirus}

In fact, the prince knew nothing about this country with various issues, but he made the acceptance of the post after receiving the promise of the Great Powers for their assistance in governance. Shortly after his arrival in Durres, Prince was faced with problems which were related directly with the determination of the borders of Albania, and with the extent 
of his power in the entire country. Despite that the borders of South Albania were already determined with the Protocol of Florence, Greece had not yet retreated its troops from South Albania (Akademia shkencave, 2007, pg.58). It claimed that this part of Albania, which was called by Greece as Northern Epirus, was inhabited by a Greek population. In fact, this claim remained partially true, because there was a number of Greeks who lived in these territories, but this was a small minority who came here centuries ago (Valentina Duka, 2007, pg. 35).

With this coming off, Greece managed to convince Europe and take a piece of land in south of Albania, and this also for the reason that Europe failed to recognize the history of the Albanian people, despite the efforts of the Albanian patriots.

With the coming of Prince Wilhelm in the reign, and the pressure of the Great Powers who gave an ultimatum to Greece to retreat the troops from 1 to 31 March 1914, putting to its attention the implementation of the Protocol of Florence. The Greeks were forced to pull their troops from Albanian territories. (Akademia Shkencave, 2007, pg.60-61).

This proved to be only a maneuver of them, because very soon Greeks encouraged the creation of a new movement against the regime of the Prince, who demanded the autonomy of the North - Epirus. This movement was called "The movement for Autonomy of Northern Epirus". Participants in this movement were Albanians filogreek and some Greek forces, which had remained here after the retreatment of Greek troops from Korça, waiting to be reactivated. (Akademia Shkencave, 2007, pg.60-61). Their actions were violent, burning villages and massacring the innocent population, which refused to be part of this movement.

To formalize this motion, a congress was held in Gjirokastra, which announced in March 2, 1914 the autonomy of Northern Epirus and his provisional government, on the head of which was placed Jorgji Zografos, the former Greek Minister of Foreign Affairs originating from Gjirokastra. He said that he would not accept the intervention of the Great Powers, and even of the Prince or the Greece. Problems would increase even more, when the same did the himarian, Spiro Spiromilo, who declared the autonomy of Himara together with its 7 villages.(Valentina Duka, 2007, pg. 6465). Wied itself and the government of Durres were concerned, they strongly rejected the claims of Zografos and the violent actions in Korça, and they even hired some armed troops.

Seeing the situation, ICC, with the proposal of Austria-Hungary, was of the opinion that, to "Northern Epirotans" had to be made some concessions that had to do with the guarantee of equal religious rights; the rights to the introduction of languages, spoken here, in schools; inclusion of elements from the South in Albanian army. Regarding the change of borders, requested by the Greek government, the Great Powers agreed with some border adjustments in kaza of Gjirokastra, as it was agreed with Mr. Venizelos, but regarding the change of borders in kaza of Korça, the Triple Alliance was opposed to the request because it conflicted with the decisions of the Conference of London (Valentina Duka, FO 421/292, Doc. Nr. 49, March 8, 1914 , Telegram i Sir F. Elliot për Sir Edward Grey).

The "Northern Epirus" forces clashed with the royal troops, but despite the brave fighting, it was increasingly difficult to continue resisting, and because of the fact that the movement had more than moral support from Greece. Situated in these positions, the king and the government had to decide how they should proceed in relation to this matter. Colonel Thomson, second in command of the army in Mission, was of the opinion that in this case to win should be used the "diplomacy", considering an opponent, military, very much stronger than the Prince forces. (Captain Heaton Armstrong, 2001, pg.62).

Wied decided to send as his and the government representative, Colonel Thompson, to negotiate with Zografos and to recover the southern provinces. A military very prepared, but not with much experience in the field of diplomacy (Arben Puto, 2009, pg . 136).

As a place for negotiation was assigned the Greek island of Corfu, whose decision will be known as the "Protocol of Corfu". In fact the negotiations were held twice, on 10 March and 17 May. In this meeting, Thompson negotiated with the representative of the government of "Northern Epirus", Karapanos, a deputy of Arta at the Chamber of Deputies in Greece, and now Minister of Foreign Affairs in the government of Zografos (Valentina Duka, 2007, pg.65) .

At the first phase of negotiation, were presented by the "Northern Epirotans", some very ambitious claims, which meant a detachment of southern Albania. Regions of Gjirokastra and Korca will be passed under the administration of a local government and gendarmerie. Albanian government forces had no right to interfere, just in case of war. In schools would be obligatory the Greek language for a population that was predominantly Albanian and with Albanian as mother language .(Arben Puto, 2009, pg. 137).

The decisions of the Protocol of Corfu flagrantly violated the decisions of the London Conference over the sovereignty of Albanian lands. These decisions were not well received by the Albanian government, which accused Colonel Thompson for exceeding the powers. She rightly claimed that the powers conferred by the Prince to the Colonel had to do with the manner of the reception of the provinces of South and the measures to maintain law and order there 
and not making the negotiations on terms of a political nature. Situated in these circumstances the Colonel gave to the Prince his resignation. The British Consul in Albania, Harry Lamb, thought that his resignation was a misfortune, because he appreciated the personality of Colonel Thompson and his skills in reorganizing the army in Albania, he was the only one who could have an effective control over the Toptani Esat Pasha, who was afraid of him. (Valentina Duka, FO 421/292, Doc. Nr. 69, 29 Mars, 1914, Telegram i Sir Edward Grey për Sir F. Elliot).

The government did not ratified the agreement made by Thompson and rejected it. In fact it seems like Colonel Thompson was an element that worked in disfavor of the Albanian state, but this is not true, because he was a capable officer, who made a great contribution to the preservation of order in a country with a difficult political situation. He lost his life in the struggle against rebels in Durres in middle of June 1914, defending order, which was part of his mission. (Arben Puto, 2009, pg. 137).

On the other hand, the Greek Foreign Minister and the Venizelos government repeatedly made request to the Great Powers and to Sir Edward Grey specifically, for a positive response regarding the boundaries of the South of Albania in favor of "Northern Epirotans", because according to him, the Greek government was in a difficult position by not having the opportunity to act in their support and keeping a backseat. The great powers had no intention to discuss more about these claims, but they guarantee the intervention for the provision of religious and linguistic rights (Valentina Duka, FO 421/292, Doc. Nr. 31, 23 Mars, 1914, telegram nga Sir Edward Grey per Sir F. Elliot).

Regarding the issue of changing the borders, the Great Powers returned the same answer back to Greece through a note proposed by the Triple Alliance, in which it was clear that some adjustments can be made on the border of Gjirokastra, but no way over Korça. (Valentina Duka, FO 421/293, Doc. Nr. 80, Prill 13, 1914, Telegram i konsullit te pergjithshem, Lamb per Sir Edward Grey).

The non ratification of the agreement of Corfu, made happen that, the pressure of "Northern Epirotans" to the local population and the government of Wied to be raised even more. A part of the filogreek population tried to provoke incidents in Korça, but the population was measured and did not responded to provocations, however, everything was planned and so to the first week of April armed gangs came burning the city. (Joseph Swire, Tirana: Dituria, 2005, pg.170).

Despite that the Greek troops, forced by the Great Powers, were retreated from the territory of South, the movement of "Northern Epirus", was aided by the Greek armed gangs. In Korça, the Greek bishop Germanos, organized a complot with some Albanian filogreeks, some Greek soldiers, who were deliberately left in hospitals, and by Greek bands (Edwin Jacques, Albanians, Tirana: Kartë dhe pendë, pg. 385). The fighting continued for about 4 days. The citizens of Korça who joined the gendarmerie forces, managed to defeat Greek bands. Greeks, with rage burned the Christian neighborhood in Korça, even though they were fighting to protect their rights (Edwin Jacques, Albanians, Tirana: Kartë e Pendë, pg. 386). The fate of the Metropolitan who was the organizer of the complot was determined by the Dutch officer, who commanded the army forces in Korça, he decided to remove him for safety reasons in Elbasan (Valentina Duka, FO 421/293, Doc. Nr. 72, 9 Prill, 1914, Telegram i konsullit te pergjithshem Lamb për Sir Edward Grey).

Although Korça was taken by Albanian government, Greek bands continued their atrocities to Albanians, but now even more terrible. Greece had thought well about the reprisals actions to Albanians, she had brought from Crete prisons, hardened criminals specifically for this job. One of the Albanian villages that suffered most from the Greek atrocities was Kodra village, situated near Tepelena. The tragedy of this village, but not only, was discussed in parliamentary debate of June 29,1914, in the Chamber of Commons in the British Parliament. The British parliamentary, Aubrey Herbert, delivered a long speech, in which he discussed the reports and facts coming from Albania about the deplorable situation of hundreds of villages raped by gangs of "Northern Epirotans". (Valentina Duka, FO 421/293, Doc. Nr. 91, 1 Maj, 1914, Telegram i konsullit te pergjithshem, Lamb to Sir Edward Grey).

Reports on the situation in villages raped, were sanded by the British consul in Albania, Mr. Lamb to Sir Edward Grey. In them he reflects the difficult situation in these villages, about the massacred population by Greek bands equipped with artillery. While in Durres, which was filled with numerous refugees, was growing the pressure on the government to take a firm decision on the occupation of the southern provinces. According to him: if the powers do not decide in favor of an active intervention, it will be very difficult for the Prince, I think, to continue to resist the popular demand for military action, despite seeming impossibilities in the measures he has in his hand. (Valentina Duka, FO 421/293, Doc. Nr. 91, 1 Maj, 1914, Telegram i Konsullit te Pergjithshem, z.Lamb për Sir Edward Grey).

Meanwhile the Athens government continued diplomatic battle. The main issue was to convince the Great Powers about the Greece's effort to calm the aggravated situation in Epirus and its exclusion of military troops from the "Vorio Epirus" troops. The removal of Greek troops from the territory of Albania in late March was not so full, so there was a 
possibility of intervention by the forces of the Great Powers for their removal and to transfer the power peacefully to the Albanian Government. The intervention of the Great Powers troops was not in the interest of Greece, so it sent a note to the ministers of the Great Powers, in which it stated that the Greek troops were now ready to be removed within the time specified by the Powers (31 March ), it pledged to maintain peace in the Greek population of "Northern Epirus" and also demanded the retreatment of the troops of the Powers, until reaching an agreement between the Albanian government and Zografos. (Valentina Duka, FO 421/292, Doc. Nr. 81, 30 Mars, 1914, telegram i Sir F. Elliot pwr Sir Edward Grey). Powers decided to retreat their troops, but they situated there a local gendarmerie organized by Dutch officers.

The situation continued to become even more difficult, while the Albanian government had absolutely no intend to accept any kind of agreement in which included a separatist regime in South provinces, a decision that was strongly backed by the British Consul in Albania, Mr. Harry Lamb. Even he couldn't accept that the Christian population can be justified in their demands for more guarantees as a Christian population, when its governed by a Christian King and is under the control of the International Commission. (Valentina Duka, FO 421/292, Doc. Nr. 73, 9 Prill, 1914, Telegram i Konsullit të Përgjithshëm, Lamb për Sir Edward Grey).

Seeing that the achievement of "Autonomy of Northern Epirus" was impossible, even for the reason that he couldn't get the support of the Great Powers, Zografos decided to give up of the claims for the political autonomy of Epirus, but now he had some new proposals and for which he expected that the Albanian government would response. The Greek Minister, hoped that with the intervention and the encouragement of the International Commission, the negotiation would be fruitful. (Valentina Duka, FO 421/293, Doc. Nr. 79, 23 Prill, 1914, Telegram i Sir F. Elliot për Sir Edward Grey).

\section{The Protocol of Corfu}

Meanwhile the situation in South provinces continued getting worse, entire villages were burning and the population was violated repeatedly. In serious fighting of the gendarmerie with the the Greek gangs, was taken and burned Erseka, and its Albanian population was massacred. The Greeks were advancing towards Frashëri and Korça. Këlcyra was partially burned by Greek troops (Valentina Duka, FO 421/293, Doc. Nr. 84, 1 Maj, 1914, Telegram i Z. Lamb për sir Edward Grey). The Dutch officers reported that the Greek artillery had protected the advancing of the gangs. 30 peasants were reported burned in the region of Kolonja and the Greek troops were advancing towards Përmet. (Valentina Duka, FO 421/293, Doc. Nr. 85, May 2, 1914 , Telegram i Z. Lamb për Sir Edward Grey).

Found in these positions, the Albanian Government made a note addressed to the Austrian and Italian Legation. Addressing to these governments, it seeks to enable an urgent evacuation of Greek troops, to end the Greek excesses against Albanians, in general and Muslims, in particular. Once presented the aggravated situation, it said that has taken into account the suggestions of Austria and Italy related to: the organization of gendarmerie and militia, and the necessity of making some impartial concessions to Epirotans. (Valentina Duka, FO 421/293, Doc. Nr. 91, 1 Maj1914, Konfidenciale, Telegrami i Z.Lamb për Edward Grey ).

So, the Albanian government to give an end to the artificially created state, (to put a regional system, which wouldn't be accepted in any way), has responded to some of the proposals made indirectly, which are presented below in a summary form:

The Orthodox communities in Albania are free to teach in their schools in Greek. Only in primary schools will be teaching in Albanian language. To take possession of the territory will be sand several detachments of gendarmerie under the command of Dutch officers, who will do some recruiting with elements of different religions in proportion with the number of the population of these religions. The Albanian army will have a unique command and will form a unit. The Sanxhak of Gjirokastra and Korça, each, will form an administrative unit. The local administration will be selected by local councils, on head of which will be the governors, elected by the central government and that would be representative of this one. The right of making petitions in Greek language for the inspector, for the villagers that speaks only Greek. The central government will come in help to the village residents affected by problems in the recent years. (Valentina Duka, FO 421/293, Dok. Nr. 91, 1 Maj, 1914, Konfidencial, Telegram i Z.Lamb për Z Edward Grey).

In response to Albanian demands for a potential deal, the Greek Foreign Minister Mr. Varatassi immediately went to Durres, after he took a notice from the Albanian government, which was willing to receive him. Even in this case, the Greeks used their tactics, implying that his arrival was not related to the notice, but at the request of the King of Greece, which, in effort of good neighborly, attempted to establish a diplomatic relation. (Valentina Duka, FO 421/293, Doc. Nr. 93, 3 Maj, 1914, Konfidencial i Z.Lamb për Edward Grey). 
Once he declared officially that it had no authority to discuss the issue of Epirus, he presented a document by which aimed to inform the Cabinet indirectly on some "minor modifications" to the Albanian proposals. The focus of these "counterproposals" was a redistribution of the regions, according to which, Himara remain under Gjirokastra, Kurvelesh , which was between the two and was entirely Muslim, was joined to Vlora, Frashëri and Tepelena were joined to Elbasan. The purpose was to create a largely Christian province in the south, and all the rest of Albania, was a widely Muslim population. So an amalgamation of all eventual Albania, after making a division in religion and language, would be reduced to a minimum. Then the South region will become a sort of Greek Eastern Rumelia, which with the earliest opportunity will be annexed by Greece. (Valentina Duka, FO 421/293, Doc. Nr. 93, 3 Maj, 1914, Konfidencial , Telegram i Z.Lamb për Sir Edward Grey).

In the management of the situation between the Albanian and the Epirus was needed the mediation of the International Commission. So the government of Turhan Pasha unanimously, invited the International Commission, to take over the implementation of the principles proposed by the Albanian government. (Valentina Duka, FO 421/293, dock. Nr. 93, 3 Maj 3, 1914, Konfidencial i Z.Lamb për Z. Edward Grey). Zografosi also agreed with the invitation for the Commission as an intermediary.

The Commission agreed and decided to take on the role of mediator between the Albanian and Epirotans, but with the condition to be provided that the current hostilities by Epirotans to go to an end, on the other hand it will stop any advance of Albanians and after taking this surely it will leave immediately to Saranda. This decision, the Commission forwarded to Mr. Zografos to. (Valentina Duka, FO 421/293, Doc. Nr. 96, 5 Maj, 1914, Z.Lamb për Z Edward Grey). Zografos promised to stop fighting in order to begin negotiations. Immediately after that, the Commission went on to Saranda to launch negotiations. (Valentina Duka, FO 421/293, Doc. Nr. 92, 7 Maj, 1914, Z.Lamb për Z. Edward Grey).

The Commission held four conferences with the gentlemen Karapanos and Zografos, who had risen during this time, their demands, even more than those presented by Mr. Varatassi. However despite the arrogance and uncompromising chauvinism of Zografos, almost was reached a kind of understanding about the language issues, school and army. The Epirius delegates were forced to abandon the requirement regarding the merger of Gjirokastra and Korça in one. Another issue that was discussed was the position of those Orthodox communities in Epirus, for which was insisted on maintaining the "rights and privileges" of the Ecumenical Patriarchate. (Valentina Duka, FO 421/293, Doc. Nr. 103, 17 Maj, 1914, Z. Lamb për Z Edward Grey).

For the manner of the reception of the provinces by the Albanian was agreed to left it to the Commission of Control and the Dutch officers. The Epirotans tried to join the specific claims of Spiro Milo, who appeared himself at the hearing of 17 May, widely exposing his major requirements and stating that if they weren't taken into consideration, he will continue his efforts with those disgruntled elements in Epirus that could take away. With reservations, the Commission decided to put in a paragraph, his request, for an evaluation by the Powers, but it wasn't included into the agreement (Valentina Duka, FO 421/293, Doc. Nr. 103, 17 Maj, 1914, Z. Lamb per Z Edward Grey).

The Commission was found in difficulty about the fact that how these requirements will be seen, apparently quite reasonable for a local view, but problematic in an inclusive aspect. Any privilege granted to South will have its consequences in the North, making more difficult the merging of these regions into homogeneous state (Valentina Duka, FO 421/293, Doc. Nr. 103, 17 Maj 1914,i Z.Lamb për Z. Edward Grey).

The delegates of Epirus clearly implied that they interpreted the right of local councils to develop their own budgets, such as the right to spend the richness of South only within its borders, when is known that the South is the richest part of Albania. The omissions formulated in this way, where summarized in an administrative autonomy of both these provinces, whose boundaries should be arranged in such a way that can maximally reduce the Muslim majority and the administration of which will be made from elements mainly came from Greece and that have run the "movement Epirus." (Valentina Duka, FO 421/293, Doc. Nr. 103, 17 Maj, 1914, Z. Lamb për Z Edward Grey).

The negotiations on proposals submitted by Zografosi, on May 17 in Corfu, were presented for ratification by the International Commission to the Albanian Government, , and also for the approval by the Congress of Northern Epirus. The achievements of the agreement during the negotiation do not include Himara, only if it would be accepted by her.

The decisions of the Corfu Agreement were approved, also by the respective governments of the Great Powers and therefore were only to be confirmed by the Albanian government and the Assembly of Epirus. This one, when was expected this approval, announced to the International Commission, that the Assembly would meet after having a response from Prince Wied about Himara provisions, provisions that were not included in the agreement, as well as some other requirements regarding the administrative subdivision of the country, which were rejected by the Commission. This announcement was just a pretext to reject the agreement reached in Corfu and to keep occupied the 
South provinces, considering also the fact of the difficult political situation in the center of Albania. (Valentina Duka, FO 421/293, Doc. Nr. 127, June 12, 1914, Z. Lamb për Sir Edward Grey).

The Albanian government accepted the Corfu agreement with some remarks which were submitted through a memorandum, to the International Commission on June 4, 1914, in which it declares its acceptance of the application, by the conditions that the points of agreement will not bring any violations to the development and national unity. (Valentina Duka, FO 421/293, Doc. Nr. 120, Qeshor 5, 1914, Z. Lamb per Z Edward Grey). The Government also stated again to the International Commission on June 20, that it will not accept the new proposals of Zografos, as they affect the independence, integrity and unity of Albania. (Valentina Duka, FO 421/293, Doc. Nr. 139, Qeshor 26, 1914, Z. Lamb per Z Edward Grey).

The Protocol of Corfu was not approved by the government of the "Northern Epirus". The Epirus and Greek forces, although they accepted a truce while were held the negotiations for the Protocol of Corfu, advanced with their troops, occupying Korça and even further in north. The International Commission failed in its commitment to the implement of the Protocol of Corfu. This issue will be further complicated because Europe will soon be included in the First World War and the Albanian question will be left behind.

\section{Conclusions}

The Movement of "North - Epirus" was a separatist movement, promoted and later strongly aided by Greece with the main intention for the southern secession, which also constitute the richest part of Albania.

The larger consequences of this movement fell on the local population, which was mostly Muslim, but also on Christians. The violence was incredible, the Greek massacres and atrocities, caused the indignation of various political personalities of Europe. There were some of them that had fought a lot for the Albanian question, struggling mightily with their speech in the press of the time and in various parliamentary debates. One of the best friends of Albania, which has given a tremendous help, regardless of the consequences that could have been on his political career, was the British parliamentarian Aubrey Herbert.

In the parliamentary debate of June 29, 1914, in the Chamber of Commons in the British Parliament, Aubrey Herbert, delivered a long speech, in which he discussed the reports and facts coming from Albania on the deplorable situation of hundreds of villages raped by gangs of the "Northern Epirotans". One of the Albanian villages that suffered most from the Greek atrocities was the Hill (Kodra) village, situated near Tepelena. The tragedy of this village, but not only, was discussed in his speech. He says:

The Hill Village is used as a slaughterhouse, where groups of Muslims and Albanians were brought in different days and there was a slaughter. The massacre reported in Hill Christian Church (Hormovë) was just the latest in their series. Here, these poor people were locked inside and Epirotans regular soldiers went up to the roof of the church, removed some tiles and with their army rifles opened fire on defenseless people... I have a list with the names of 205 people killed in Hillside and I verified it. The Epirus Government accepts almost all the facts, but I am convinced that the guilty parties go beyond ... Therefore the Greek government that instructed Mr. Gennadius in London to deny the massacres, knew that the massacre had happened .... even they knew it all ..... my full report will be accompanied with facts. (Bejtullah Press Jason Tomes, 2012, pg.223-225).

The statements of Aubrey Herbert were further confirmed by the General Dee Veer of the Dutch Mission, who saw with his own eyes the massacres of Greeks in the village and photographed the terrible images. In his report directed to the International Commission of Control, he describes with even more details the atrocities and declares the exhumation of 195 bodies, which were buried in a shallow grave, putting them in proper graves. All the bodies were headless. The massacred population in the village was not Muslim, but Albanian Christian (Edwin Jacques, Tirana: Karte e Pende, faqe. 386).

The Colonel Herbert continued his battle to protect the Albanian issue through British press. He published continuously in prestigious newspapers like The Times and The Morning Post, which were published in London, different facts coming from the developments in Albania, hoping in the sensitization of the British Government for an oppressed people, whose state was created by The Great Powers with the leading role of Great Britain, and was her responsibility to raise the voice for the protection of this state and this people. (Bejtullah Press, Jason Tomes, 2012).

The Greek atrocities will continue even further in other villages outside of Korça, in the district of Kolonja. In the parliamentary debates of June 29, 1914 in the Chamber of Commons, Aubrey Herbert denounced this massacres in his speech as following: 
In the district of Cologne ... (1 Maj) 55 houses were burned Muslim village of Qinam, with massacres and mutilations. In Staria, 120 houses burned and slaughters etc. In Leskovik 2200 houses burned, in Frashër 150 houses burned. (Bejtullah Destani, Jason Tomes, 2012, pg. 226)

For the atrocities of Kolonja and its villages was written as well in the newspapers of the patriots abroad, like the Newspaper of Sofia The Freedom of Albania, which published a letter from the Kolonja area. In the article was spoken about the atrocities of the andartes (the holy battalions of the epirotans). Borova was robbed and 13 women, were dishonored with the violence, in Rehova and Gostivisht also,. In Luaras, 20 Muslim children were slaughtered. In Panarit, also, 300 people were slaughtered, they said to them, that they could return home, then they killed them with axes (Edwin Jacques, Tirana: Karte e Pende, pg. 387-389).

The reports were coming, as well from the American journalist William Howard. From his contacts with Harold Spencer, an American volunteer at the headquarters of Prince Wied, he provided some information. Spencer testified about the events that he personally observed, especially in the village of Qinan. After having expelled the Greek troops, he was faced with the massacre there. The Greeks had raped five young women, which were found naked. One of them was raped 27 times. Others, who had fought for their honor, were killed and their bodies were raped by the Greeks. His testimonies, also come for the Bocka village, where the Greek troops killed more than 200 women, children, babies and also for Hormova village, where 225 farmers were massacred.(Edwin Jacques, Tirana: Karte e pende, pg. 387-389).

These massacres make even clearer the actions of the Greeks in the territories that were and are part of the Albanian state.

\section{References}

Puto, A.,(2009) Shqipëria politike 1912-1939,Tiranë : Toena, 2009

Destani, B.; Tomes, J.,(2012) Miku i madh i shqiptarëve Aubrey Herbert dhe krijimi i Shqipërisë së sotme, Tiranë: Via Egnatia, 2012

Jacques, E., Shqiptarët, Tiranë: Kartë e Pendë

Akademisë së Shkencave,(2007), Historia e Popullit Shqiptar Vell.III,Tiranë: Toena, 2007

Swire, J.,(2005), Shqipëria: Ngritja e një mbretërie Tiranë: Dituria, 2005

Armstrong, H.,(2001) Gjashtë muaj mbretëri 1914, Kujtime,Tiranë: Onufri, 2001

Duka, V., (2007)Histori e Shqipërisë 1912-2000, Tiranë: ShBLSH, 2007

Duka, V.,(2012) Dokumente Britanike për Shqipërinë e Shqiptarët Vëll. II, Tiranë: Toena, 2012

FO 421/292, dok. Nr. 49, FO 421/292, dok. Nr. 69, FO 421/292, dok. Nr. 31,

FO 421/293, dok. Nr. 80, FO 421/293, dok. Nr. 72, FO 421/292, dok. Nr. 81,

FO 421/292, dok. Nr. 73, FO 421/293, dok. Nr. 79, FO 421/293, dok. Nr. 84,

FO 421/293, dok. Nr. 85, FO 421/293, dok. Nr. 91, FO 421/293, dok. Nr. 92

FO 421/293, dok. Nr. 93, FO 421/293, dok. Nr. 96, FO 421/293, dok. Nr. 103

FO 421/293, dok. Nr. 127, FO 421/293, dok. Nr. 120, FO 421/293, dok. Nr. 139

Konica, Faik,(1913) ,"Të zgjedhurit e Mbretit", Dielli, November 7, 1913

Taraboshi,(1913) , Shkodër "Princi Wied",Taraboshi, 4 tetor, 1913 